\title{
BOOKS AND OTHER PUBLICATIONS RECEIVED
}

Boddewyn, J.J., and Marton, Katherin. Comparison Advertising: A Worldwide Study. New York: Hastings House, 1978

Connor, John M. The Market Power of Multinationals: A Quantitative Analysis of U.S. Corporations in Brazil and Mexico. Praeger Special Studies. New York: Praeger Publishers, 1977.

Coolidge, Philip; Spina, George C.; Wallace, Don, Jr., eds. The OECD Guidelines for Multinational Enterprises: A Business Appraisal. Washington: The Institute for International and Foreign Trade Law, Georgetown Universtiy Law Center, 1977.

Feinschreiber, Robert. International Tax Planning Today. Greenvale, N.Y., 1977.

Stobaugh, Robert B. Nine Investments Abroad and Their Impact at Home: Case Studies on Multinational Enterprises and the U.S. Economy. With the collaboration of J. de la Torre, Jr.; R.H. Hayes; J.V. Jucker; R.W. Moxon; R.M. Rodriguez; J.G. Keddie; P. Nueno; J. Pogrow; R.C. Ronstadt; P. Telesio; P.L. Townsend. Cambridge, Mass. and London: Harvard University Press, 1976.

Tsurumi, Yoshi, The Japanese Are Coming. Cambridge, Mass.: Ballinger, 1976.

U.N. Centre on Transnational Corporations. Survey of Research on Transnational Corporations. New York: United Nations, 1977.

Vambery, Robert G. Capital Investment Control in the Air Transport Industry. Dobbs Ferry: Oceana Publications, 1977.

Vernon, Raymond. Storm over the Multinationals: The Real Issues. Cambridge, Mass. Harvard University Press, 1977.

\section{OTHER}

"Boundaries and Big Business: The Regulation of Multinational Corporations." Journal of Contemporary Business 6:4 Autumn 1977. Seattle: Graduate School of Business Administration of the University of Washington.

\section{EDITOR'S NOTE}

Book reviews will be selected in the future from the books listed above and from others subsequently received. The listing of a book does not assure a review of the book in JIBS. 